\title{
Pengaruh Jenis dan Konsentrasi Penstabil Terhadap Karakteristik Fisikokimia dan Nilai Kesukaan Minuman Yogurt Jeruk
}

\section{Effect of Type and Concentration of Stabilizer on Physicochemical Characteristics and Preference Value of Orange Yogurt Drink}

\author{
Trifena Honestin ${ }^{1}$, Imro'ah Ikarini², Yunimar ${ }^{3}$ \\ ${ }^{1,2,3}$ Balai Penelitian Tanaman Jeruk dan Buah Subtropika, Kementerian Pertanian
}

\section{ARTICLE INFO \\ Article history: \\ DOI: \\ $\underline{10.30595 / p s p f s . v 2 i .181}$}

Submitted:

July 29, 2021

Accepted:

Sept 10, 2021

Published:

Nov 10, 2021

\section{Keywords:}

Yogurt, Penstabil, Fisikokimia, Organoleptik

\begin{abstract}
Orange yogurt drink is one of the diversivication of yogurt products, but syneresis still often occurs during the storage period which can affect consumer assessments. Therefore, it is necessary to add a stabilizer to overcome this problem. The purpose of this study was to determine the effect of different types of stabilizers and the concentration level of stabilizers added to the physicochemical characteristics and preference of orange yogurt drinks. Characteristics of yogurt drinks that were observed included $\mathrm{pH}$ values, Total Titrated Acid/TAT, Total Dissolved Solids/TPT, vitamin $\mathrm{C}$, wheying off, viscosity, and organoleptic tests which included preference for color, aroma, texture appearance and taste of orange yogurt drinks This study uses a completely randomized design (CRD) with two factors, namely the type of stabilizer (Carboxy Methyl Cellulose/CMC, pectin, gum arabic) and the concentration of stabilizer $(0.01 \%, 0.03 \%$, and $0.05 \%)$. The results of this study indicate that $\mathrm{pH}$ value of the orange yogurt drink ranged from 3.907-4.058, total soluble solids (TPT) of the orange yogurt drink was $14.350-16,367{ }^{\circ}$ Brix, vitamin $\mathrm{C}$ content of the orange yogurt drink was between $6.453-10.560 \mathrm{mg} / 100 \mathrm{~g}$, and TAT value. $6.133-8.067 \%$. The treatment of different types of stabilizers affects the physicochemical characteristics of orange yogurt drinks, including the value of $\mathrm{pH}$, TPT, vitamin $\mathrm{C}$, TAT, wheying off and viscosity. While the treatment of different concentrations of stabilizer affects the wheying off and the viscosity of the orange yogurt drink. The results of the interaction between the type and concentration of stabilizer significantly affect the value of $\mathrm{pH}$, vitamin $\mathrm{C}$, TAT, wheying off, viscosity also the value of preference for color, appearance and texture of orange yogurt drink.
\end{abstract}

This work is licensed under a Creative Commons Attribution 4.0 International License.

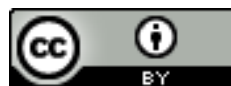

Corresponding Author:

Trifena Honestin

Balai Penelitian Tanaman Jeruk dan Buah Subtropika, Kementerian Pertanian

Email: trifenahonestin@gmail.com

\section{PENDAHULUAN}

Yogurt merupakan salah satu produk fermentasi susu yang disukai masyarakat. Menurut Standar Nasional Indonesia (SNI) yang disusun oleh Badan Standardisasi Nasional, yogurt adalah produk yang diperoleh dari fermentasi susu dan atau susu rekonstitusi dengan menggunakan bakteri Lactobacillus bulgaricus 
dan Streptococcus thermophillus dan atau bakteri asam laktat lain yang sesuai, dengan/atau tanpa penambahan bahan pangan lain dan bahan tambahan pangan yang diizinkan (Badan Standardisasi Nasional, 2009).

Menurut Faisal et al., (2019) mengkonsumsi yogurt dapat meningkatkan sistem kekebalan tubuh, mengontrol berat badan, meningkatkan pencernaan dan penyerapan nutrisi, mengurangi atau menghilangkan bakteri jahat di saluran pencernaan, menormalkan fungsi usus besar (mengatasi sembelit dan diare), mengurangi risiko penyakit, dan berkontribusi pada detoksifikasi dan manajemen stres. Peningkatan konsumsi yogurt disebabkan oleh sifat-sifat fungsionalnya terhadap kesehatan dan juga meningkatnya diversifikasi produk yogurt, salah satunya adalah dalam bentuk minuman yang tidak kental dimana kandungan padatan susunya lebih rendah dibandingkan jenis yogurt lain (Jannah et al., 2014). Selain itu ada juga dengan penambahan buah untuk meningkatkan nilai tambah yogurt. Minuman yogurt atau yogurt drink juga memenuhi kebutuhan konsumen yang menyukai kepraktisan.

Yogurt buah diproduksi dengan menambahkan konsentrat buah atau sari buah yang memiliki cita rasa pada susu starter sebelum atau sesudah proses inkubasi, akibatnya penambahan bahan perasa biasanya menurunkan tekstur produk. Di sisi lain, penambahan rasa menyebabkan peningkatan nilai gizi produk dan keragamannya di pasaran (Al-Bedrani et al., 2019). Jeruk manis yang merupakan sumber daya lokal Indonesia layak dikembangkan dan dimanfaatkan untuk memberi nilai tambah pada produk yogurt. Hal ini dikarenakan jeruk manis merupakan buah yang digemari masyarakat baik sebagai buah segar maupun olahan dan dapat dikonsumsi oleh masyarakat berpendapatan rendah hingga yang berpendapatan tinggi (Oni, Wa, Bahari, 2019). Selain itu jeruk merupakan salah satu tanaman buah yang memiliki kandungan vitamin $\mathrm{C}$ yang cukup tinggi diantara berbagai jenis buah lainnya dan memiliki manfaat yang sangat baik bagi kesehatan tubuh. Jeruk manis yang banyak dikembangkan di Indonesia yaitu varietas Manis Pacitan dengan sentranya di Jawa Timur dan cocok ditanam di daerah dataran rendah maupun tinggi (Balitjestro, 2020).

Salah satu kriteria mutu yogurt yang diperhatikan ialah konsistensi atau kekentalan dan kestabilan. Selain aspek fisik, kualitas sensorik dan nilai gizi makanan dapat berubah sesuai dengan bahan yang ditambahkan. Berbagai jenis bahan tambahan makanan digunakan selama pembuatan minuman yogurt, dan penstabil/stabilisator memainkan peran utama diantara aditif ini. Peran tersebut terkait dengan permasalahan yang terjadi pada yogurt selama penyimpanan yaitu sineresis dimana terbentuk cairan pada permukaan yogurt atau dikenal dengan whey. Penstabil dapat mengurangi sineresis serta sebagai bahan pengikat air dengan cara meningkatkan sifat hidrofilik protein. Ikatan hidrogen antara molekul air dan protein melemah dan pori-pori di antara molekul kasein melonggar, sehingga dapat dilalui oleh air (Widianti, 2018). Beberapa jenis penstabil yang dapat digunakan dalam minuman sesuai dengan Peraturan Kepala Badan Pengawas Obat dan Makanan nomor 19 tahun 2019 tentang Bahan Tambahan Pangan (BTP), diantaranya CMC (Carboxy Methyl Cellulose), pektin, dan gom arab.

CMC adalah polisakarida yang digunakan dalam susu yang diasamkan/yogurt dan digunakan sebagai pembentuk gel, penstabil, atau zat pengental dalam produk susu (Yousefi and Jafari, 2019). Sebayang (2019) memanfaatkan CMC dari kacang tanah (Arachis hypogaea L) sebagai penstabil yogurt susu sapi dan menunjukkan bahwa yogurt dengan penambahan CMC 0,3\% memberikan hasil terbaik dengan aroma khas, rasa asam, dan tekstur agak kental serta dapat mengurangi sineresis dengan meningkatkan stabilitas sampai $85 \%$. Arkan et al., (2021) menggunakan pektin 0,8\% sebagai stabilizer dalam pembuatan yogurt susu sapi. Sedangkan menurut Jasim et al., (2018), penambahan gum arab sebesar 1\% dapat meningkatkan tekstur dan sifat sensorik yogurt susu unta tanpa mempengaruhi penerimaan konsumen. Hasil penelitian Salih et al., (2020) juga menunjukkan bahwa yogurt dengan penambahan gom arab pada konsentrasi $0,2,0,35$, dan $0,5 \%$ menyebabkan sineresis yang lebih sedikit (1,6 1,4, dan 3,3 ml/l setelah 9 hari.

Penambahan bahan penstabil membantu mencegah sineresis, sekaligus memperbaiki bentuk, tekstur, penampilan dan rasa yogurt di mulut. Oleh karena itu, tujuan dari penelitian ini adalah untuk mengevaluasi sifat fisikokimia dan nilai kesukaan minuman yogurt jeruk dengan penggunaan penstabil khususnya CMC, pektin, dan gom arab pada tingkat konsentrasi yang berbeda.

\section{METODE PENELITIAN}

Metode yang digunakan dalam penelitian ini adalah metode pembuatan minuman yogurt yang mengikuti prosedur Wahyudi (2006) dengan modifikasi, serta pengujian karakteristik minuman yogurt seperti pengukuran pH (metode Wahyudi, 2006), Total Asam Tertitrasi/TAT (metode Sudarmadji et al., 1997), Total Padatan Terlarut/TPT (metode AOAC, 2005), vitamin C (metode iodimetri AOAC, 1995), wheying off (metode Prayitno et al., 2020 dengan modifikasi) serta viskositas (metode Djurdjevic-Denin et al., 2002), sedangkan uji organoleptik hedonik/kesukaan warna, aroma, penampakan tekstur dan rasa, dilaksanakan oleh 31 panelis. Penelitian ini dirancang menggunakan Rancangan Acak Lengkap dengan 2 (dua) faktor yaitu perbedaan jenis penstabil (CMC, pektin, gom arab) dan tingkat konsentrasi $(0,01 \%, 0,03 \%, 0,05 \%)$ dengan 3 (tiga) kali ulangan. Data yang dihasilkan dianalisis dengan menggunakan software Minitab 19. Penelitian ini dilaksanakan di Laboratorium Pascapanen Balai Penelitian Tanaman Jeruk dan Buah Subtropika, Kota Batu, Jawa Timur. 
Bahan

Bahan-bahan yang digunakan dalam penelitian ini adalah susu sapi murni yang diperoleh dari Dinas Peternakan (Kota Batu, Jawa Timur), starter yogurt merk Biokul yang berisi kultur bakteri S. thermophilus, L. bulgaricus, L. acidophilus, dan Bifidobacterium, jus jeruk manis, air mineral, gula, CMC, pektin, gom arab, serta bahan-bahan kimia untuk analisis TAT dan vitamin C.

Alat

Peralatan yang digunakan dalam penelitian ini antara lain kompor, inkubator Memmert (Schwabach, Jerman), pH meter AMTAST (USA), refraktometer HANNA Instruments (USA), viskometer Brookfield (Stoughton, USA) serta alat-alat laboratorium untuk analisis TAT dan vitamin C.

\section{HASIL DAN PEMBAHASAN}

Data analisis keragaman pengaruh jenis penstabil dan konsentrasi penstabil terhadap karakteristik minuman yogurt jeruk disajikan pada Tabel 1. Hasil analisis keragaman menunjukkan bahwa perbedaan jenis penstabil dan konsentrasinya berpengaruh signifikan terhadap $\mathrm{pH}$, vitamin $\mathrm{C}$, TAT, wheying off dan viskositas ( $p$ value $\leq 0,05)$, namun tidak memberikan pengaruh yang signifikan terhadap TPT ( $p$ value $>0,05)$.

Tabel 1. Pengaruh jenis dan konsentrasi penstabil terhadap pH, TPT, vitamin C, TAT, wheying off dan viskositas.

\begin{tabular}{lccccccc}
\hline $\begin{array}{c}\text { Jenis } \\
\text { Penstabil }\end{array}$ & $\begin{array}{c}\text { Konsentrasi } \\
\text { Penstabil (\%) }\end{array}$ & $\mathrm{pH}$ & $\begin{array}{c}\text { Total Padatan } \\
\text { Terlarut } \\
\left({ }^{\circ} \text { Brix }\right)\end{array}$ & $\begin{array}{c}\text { Vitamin C } \\
(\mathrm{mg} / \\
100 \mathrm{~g})\end{array}$ & $\begin{array}{c}\text { Total Asam } \\
\text { Tertitrasi }(\%)\end{array}$ & $\begin{array}{c}\text { Wheying } \\
\text { off }(\%)\end{array}$ & $\begin{array}{c}\text { Viskositas } \\
(\mathrm{m} . \text { Pa.s })\end{array}$ \\
\hline CMC & 0,01 & $4,008^{\mathrm{b}}$ & $14,683^{\mathrm{a}}$ & $9,387^{\mathrm{ab}}$ & $7,067^{\mathrm{abc}}$ & $2,237^{\mathrm{cd}}$ & $336,667^{\mathrm{bc}}$ \\
$\mathrm{CMC}$ & 0,03 & $3,907^{\mathrm{c}}$ & $14,650^{\mathrm{a}}$ & $6,453^{\mathrm{b}}$ & $7,133^{\mathrm{abc}}$ & $1,402^{\text {cd }}$ & $350,000^{\mathrm{abc}}$ \\
CMC & 0,05 & $3,913^{\mathrm{c}}$ & $14,983^{\mathrm{a}}$ & $8,213^{\mathrm{ab}}$ & $8,067^{\mathrm{a}}$ & $3,497^{\mathrm{cd}}$ & $308,333^{\mathrm{bcd}}$ \\
Pektin & 0,01 & $3,918^{\mathrm{c}}$ & $15,350^{\mathrm{a}}$ & $9,973^{\mathrm{a}}$ & $7,733^{\mathrm{ab}}$ & $0,336^{\mathrm{d}}$ & $410,000^{\mathrm{a}}$ \\
Pektin & 0,03 & $3,885^{\mathrm{c}}$ & $14,783^{\mathrm{a}}$ & $9,973^{\mathrm{a}}$ & $7,733^{\mathrm{ab}}$ & $3,495^{\mathrm{bc}}$ & $370,000^{\mathrm{ab}}$ \\
Pektin & 0,05 & $3,908^{\mathrm{c}}$ & $14,967^{\mathrm{a}}$ & $10,560^{\mathrm{a}}$ & $7,067^{\mathrm{abc}}$ & $6,991^{\mathrm{cd}}$ & $248,333^{\mathrm{de}}$ \\
Gom Arab & 0,01 & $3,903^{\mathrm{c}}$ & $15,500^{\mathrm{a}}$ & $10,560^{\mathrm{a}}$ & $7,000^{\mathrm{abc}}$ & $6,012^{\mathrm{cd}}$ & $280,000^{\mathrm{d}}$ \\
Gom Arab & 0,03 & $4,047^{\mathrm{ab}}$ & $15,967^{\mathrm{a}}$ & $10,560^{\mathrm{a}}$ & $6,133^{\mathrm{c}}$ & $13,142^{\mathrm{b}}$ & $186,667^{\text {ef }}$ \\
Gom Arab & 0,05 & $4,058^{\mathrm{a}}$ & $16,367^{\mathrm{a}}$ & $7,627^{\mathrm{ab}}$ & $6,600^{\mathrm{bc}}$ & $27,907^{\mathrm{a}}$ & $135,833^{\mathrm{f}}$ \\
\hline
\end{tabular}

Keterangan : Huruf yang berbeda menunjukan perbedaan nyata berdasarkan uji lanjut Tuckey pada taraf $5 \%$.

\section{Nilai pH}

Nilai pH menunjukkan derajat keasaman minuman yogurt dan berkaitan dengan asam yang dihasilkan. Hasil analisis statistik menunjukkan bahwa perbedaan jenis dan konsentrasi penstabil yang dipakai dalam penelitian ini berpengaruh signifikan $(p$ value $\leq 0,05)$ terhadap nilai $\mathrm{pH}$ minuman yogurt jeruk. Nilai $\mathrm{pH}$ minuman yogurt jeruk berkisar antara 3,903 - 4,058. Hal ini sesuai dengan pernyataan Farinde et al., (2010) bahwa yogurt yang baik mempunyai nilai $\mathrm{pH}$ berkisar 3,8 - 4,6. Selama proses fermentasi, bakteri asam laktat akan memfermentasi karbohidrat yang ada hingga terbentuk asam laktat. Pembentukan asam laktat ini menyebabkan peningkatan keasaman dan penurunan nilai $\mathrm{pH}$ minuman yogurt. Penambahan pektin dan $\mathrm{CMC}$ seiring dengan peningkatan konsentrasi memberikan pengaruh penurunan $\mathrm{pH}$ minuman yogurt jeruk dibandingkan dengan gom arab. Perubahan nilai $\mathrm{pH}$ minuman yogurt cenderung menurun selama penyimpanan disebabkan terakumulasinya asam organik hasil fermentasi glukosa menjadi asam oleh bakteri asam laktat (Widianti, 2018). Penurunan pH biasanya berdampak pada peningkatan nilai keasaman atau TAT seperti pada penelitian Aprilia et al., (2019).

\section{Total Padatan Terlarut (TPT)}

Mutu yogurt juga ditentukan oleh kandungan padatan terlarut pada yogurt. Total padatan terlarut menunjukkan banyaknya kandungan bahan-bahan yang terlarut dalam produk. Nilai TPT akan mempengaruhi tekstur minuman yogurt yang dihasilkan. Hasil analisis statistik menunjukkan bahwa TPT tidak dipengaruhi oleh perbedaan jenis dan konsentrasi penstabil yang dipakai dalam penelitian ini ( $p$ value $\geq 0,05)$. Namun dari data penelitian didapatkan bahwa TPT tertinggi terdapat pada minuman yogurt jeruk yang menggunakan gom arab $0,05 \%$. Hal ini diduga karena sifat kelarutan dari gom arab yang tinggi. TPT minuman yogurt jeruk berkisar antara 14,350-16,367 ${ }^{\circ}$ Brix dan telah memenuhi standar SNI 01- 2981-2009 dimana TPT pada yogurt minimum 8,2\%. Jumlah TPT minuman yogurt ini sudah sesuai dengan pernyataan Tamime \& Robinson, (2000), dimana yogurt yang baik memiliki nilai TPT berkisar antara $14-16^{\circ}$ Brix. 


\section{Kadar Vitamin C}

Hasil analisis statistik menunjukkan bahwa kadar vitamin $\mathrm{C}$ minuman yogurt jeruk dipengaruhi oleh jenis penstabil dan konsentrasi penstabil ( $p$ value $\leq 0,05$ ). Kadar vitamin $\mathrm{C}$ minuman yogurt jeruk berkisar antara $6,453-10,560 \mathrm{mg} / 100 \mathrm{~g}$. Penambahan penstabil pektin menghasilkan analisis rata-rata kadar vitamin $\mathrm{C}$ tertinggi yaitu $10,169 \mathrm{mg} / 100 \mathrm{~g}$ pada minuman yogurt jeruk. Hal ini diduga penambahan pektin dapat mempertahankan kandungan vitamin $\mathrm{C}$ pada produk karena sifat pektin dapat menyerap air sehingga semakin sedikit oksigen bebas pada produk yang dapat menyebabkan oksidasi vitamin C (Atviolani, 2016).

\section{Total Asam Tertitrasi (TAT)}

Pengukuran TAT dilakukan dengan menggunakan metode titrasi. Kadar TAT pada minuman yogurt dianggap sebagai asam laktat dikarenakan asam organik yang paling banyak dihasilkan dalam yogurt sebagai produk utama adalah asam laktat serta sedikit sekali asam sitrat yang terkandung pada jus buah jeruk. Total asam tertitrasi yogurt dipengaruhi oleh aktivitas bakteri yang mendegradasi laktosa menjadi asam laktat. Laktosa susu yang diubah menjadi asam laktat sekitar 30\% sedangkan sisanya dalam bentuk laktosa (Arkan et al., 2021). Secara umum, tingkat keasaman dalam yogurt juga dapat dipengaruhi oleh komposisi strain kultur starter, lama penyimpanan, suhu fermentasi, serta kontaminasi (Singh et al., 2011). Nilai TAT minuman yogurt jeruk berkisar antara 6,133-8,067\%. Hasil analisis statistik menunjukkan bahwa perlakuan perbedaan jenis dan konsentrasi penstabil berpengaruh nyata terhadap nilai TAT minuman yogurt jeruk ( $p$ value $\leq 0,05)$ dimana nilai TAT tertinggi terdapat pada penambahan CMC sebanyak 0,05\% dan TAT terendah pada penambahan gom arab sebanyak $0,03 \%$. Total asam tertitrasi merupakan penduga pengaruh keasaman terhadap aroma dan rasa yang lebih baik dibandingkan dengan nilai pH.(Arkan et al., 2021). Menurut Bekti et al. (2019), CMC mengandung gugus karboksil yang bersifat asam serta mudah terhidrolisis sehingga penambahan CMC dapat meningkatkan TAT.

\section{Wheying off}

Wheying pada yogurt merupakan keluarnya cairan whey yang terlihat sebagai cairan encer di atas permukaan gel yogurt (Prayitno et al., 2020). Menurut Gad and Mohamad (2014), wheying off memberikan persepsi negatif konsumen tentang yogurt karena konsumen berpikir ada sesuatu yang salah secara mikrobiologis dengan produk yogurt tersebut. Perlakuan perbedaan jenis dan konsentrasi penstabil berpengaruh nyata terhadap wheying off minuman yogurt jeruk ( $p$ value $\leq 0,05)$. Penambahan CMC rata-rata dapat mengurangi sineresis karena CMC dapat mencegah interaksi antara kasein dan asam laktat dengan mengubah muatan ion. Kasein mengalami perubahan ion dari negatif ke positif saat berinteraksi dengan CMC ketika $\mathrm{pH}$ yogurt mencapai titik isoelektrik (Sebayang, 2019). Hal ini dilihat pada data hasil penelitian dimana penambahan CMC 0,01\%, 0,03\% dan 0,05\% hanya mengakibatkan wheying off yang cukup sedikit (berturutturut $2,237 \%, 1,402 \%$, dan 3,497\%). Walaupun pada data penambahan CMC dapat mengurangi sineresis namun wheying off paling sedikit terjadi pada minuman yogurt dengan penambahan pektin $0,01 \%$ yaitu sebanyak 0,336\%. Gad dan Mohamad (2014) juga telah membuktikan bahwa pektin dapat meningkatkan stabilitas minuman yogurt karena pada $\mathrm{pH}$ rendah, molekul pektin bermuatan negatif berinteraksi dengan misel kasein yang bermuatan positif sehingga membentuk kompleks yang stabil. Data menunjukkan bahwa semakin banyak konsentrasi penstabil mengakibatkan kecenderungan peningkatan wheying off. Hal ini disebabkan karena penambahan bahan penstabil yang semakin banyak dapat mengikat protein yang lebih kuat, namun dapat merusak struktur jaringan secara parsial (keseluruhan) sehingga dapat menurunkan stabilitas (Ningsih et al., 2019). Penambahan bahan penstabil yang tinggi dapat membungkus misel kasein secara keseluruhan, sehingga menyebabkan ketertarikan antara misel kasein menurun sehingga dapat menyebabkan sineresis (Andiç et al., 2013).

\section{Viskositas}

Viskositas merupakan faktor utama dalam pencegahan pengendapan dan agregasi padatan tersuspensi dalam minuman (Gad \& Mohamad, 2014). Karakteristik viskositas menunjukkan tingkat kekentalan suatu produk. Menurut Widianti, (2018) tekstur dan kekentalan yogurt dipengaruhi oleh penambahan jenis penstabil salah satunya yaitu CMC, hal ini karena CMC merupakan jenis penstabil ester polimer selulosa yang larut dalam air sehingga akan mengikat air dalam yogurt dan meningkatkan tekstur yogurt. Penambahan CMC dapat meningkatkan viskositas minuman yogurt namun masih lebih rendah dibandingkan dengan penambahan pektin.

Hasil analisis viskositas minuman yogurt jeruk yang dihasilkan antara 135,833 - 410,000 m.Pa.s. Menurut Aini dkk. (2017) viskositas yogurt dipengaruhi oleh interaksi hidrofobik misel kasein. Interaksi ini dapat terganggu oleh produksi asam laktat yang menurunkan keasaman dan akibatnya dapat menyebabkan koagulasi kasein dan menurunkan viskositas. Selain itu Macit dan Bakirci (2017) juga melaporkan bahwa penurunan nilai kapasitas pengikatan air dan peningkatan nilai sineresis juga dapat menyebabkan penurunan viskositas. Hal ini dibuktikan dengan data yang dihasilkan dalam penelitian ini dimana semakin tinggi nilai wheying off atau sineresis minuman yogurt maka semakin turun viskositasnya. Perlakuan jenis dan konsentrasi 
penstabil memberikan pengaruh nyata $(p$ value $\leq 0,05)$ terhadap viskositas minuman yogurt jeruk dimana minuman yogurt jeruk dengan penambahan gom arab dengan konsentrasi 0,05\% memiliki viskositas terendah. Hal ini disebabkan gom arab memiliki karakteristik pengemulsi yang unik dengan sifat kelarutannya yang tinggi namun viskositasnya rendah (Fazilah et al., 2019). Sedangkan minuman yogurt jeruk dengan penambahan pektin $0,01 \%$ memiliki viskositas tertinggi yang disebabkan karena pektin memiliki sifat hidrofilik dan pektin yang larut akan membentuk suatu serabut halus dengan adanya pemanasan, dimana struktur tersebut mampu menahan cairan sehingga kandungan air pada minuman yogurt tidak dapat bergerak dengan bebas sehingga terjadi peningkatan viskositas (Atviolani, 2016). Menurut Aprilia et al., (2019) pektin memiliki sifat mampu mengikat dan menyerap air sehingga mampu membentuk gel yang lebih kuat dan meningkatkan nilai viskositasnya. Pektin membentuk gel pada kondisi kandungan gula yang tinggi dan nilai $\mathrm{pH}$ yang rendah (asam) pada suhu $60-90^{\circ} \mathrm{C}$ (Farikha et al., 2013).

\section{Nilai Kesukaan Minuman Yogurt Jeruk}

Uji organoleptik yang dilakukan adalah uji hedonik atau kesukaan pada minuman yogurt jeruk. Hasil penilaian kesukaan panelis dapat dilihat pada Tabel 2 dimana parameter yang digunakan dalam uji kesukaan (hedonik) terdiri dari empat atribut yaitu, warna, penampakan, tekstur, dan rasa. Tingkat kesukaan panelis terhadap masing-masing atribut minuman yogurt jeruk menggunakan skala 1-5 dimana semakin tinggi nilai yang diberikan, menyatakan bahwa panelis sangat menyukai produk pada atribut tersebut.

Tabel 2. Pengaruh jenis dan konsentrasi penstabil terhadap kesukaan panelis pada minuman yogurt jeruk

$\begin{array}{llllll}\text { Jenis Konsentrasi } & \text { Warna Aroma } & \text { Penampakan }\end{array}$

Penstabil Penstabil (\%)

\begin{tabular}{|c|c|c|c|c|c|c|}
\hline CMC & 0,01 & $3,806^{\mathrm{a}}$ & $3,516^{\mathrm{a}}$ & $3,968^{\mathrm{a}}$ & $3,806^{\mathrm{a}}$ & $3,710^{\mathrm{a}}$ \\
\hline $\mathrm{CMC}$ & 0,03 & $3,839^{\mathrm{a}}$ & $3,710^{\mathrm{a}}$ & $3,710^{\mathrm{a}}$ & $3,710^{a}$ & $3,839^{\mathrm{a}}$ \\
\hline CMC & 0,05 & $3,935^{\mathrm{a}}$ & $3,581^{a}$ & $3,903^{\mathrm{a}}$ & $3,742^{\mathrm{a}}$ & $3,968^{\mathrm{a}}$ \\
\hline Pektin & 0,01 & $4,032^{\mathrm{a}}$ & $3,710^{\mathrm{a}}$ & $3,774^{\mathrm{ab}}$ & $3,516^{a b c}$ & $3,548^{\mathrm{a}}$ \\
\hline Pektin & 0,03 & $3,903^{\mathrm{a}}$ & $3,806^{\mathrm{a}}$ & $3,871^{\mathrm{a}}$ & $3,677^{\mathrm{ab}}$ & $3,548^{\mathrm{a}}$ \\
\hline Pektin & 0,05 & $3,290^{\mathrm{ab}}$ & $3,516^{\mathrm{a}}$ & $3,226^{a b c}$ & $3,161^{a b c}$ & $3,290^{\mathrm{a}}$ \\
\hline Gom Arab & 0,01 & $3,903^{a}$ & $3,871^{\mathrm{a}}$ & $3,839^{\mathrm{a}}$ & $3,645^{a b c}$ & $3,806^{\mathrm{a}}$ \\
\hline Gom Arab & 0,03 & $3,032^{b}$ & $3,387^{\mathrm{a}}$ & $3,032^{b c}$ & $2,839^{\mathrm{c}}$ & $3,484^{\mathrm{a}}$ \\
\hline Gom Arab & 0,05 & $3,032^{\mathrm{b}}$ & $3,355^{\mathrm{a}}$ & $2,839^{\mathrm{c}}$ & $2,871^{b c}$ & $3,290^{\mathrm{a}}$ \\
\hline
\end{tabular}

Keterangan : Huruf yang berbeda menunjukan perbedaan nyata berdasarkan uji lanjut Tuckey pada taraf 5\%.

Kualitas suatu produk salah satunya dipengaruhi oleh penilaian konsumen, semakin tinggi penilaian produk maka kualitas produk akan semakin meningkat (Gaol \& Hidayat, 2016). Penilaian atribut warna menggunakan indera penglihatan oleh panelis. Berdasarkan uji statistik, penambahan variasi bahan penstabil dengan berbagai konsentrasi menunjukkan hasil yang berbeda nyata. Hal ini diduga karena warna putih pada yogurt memiliki intensitas yang berbeda menurut penilaian panelis. Dari hasil pengujian sensori pada atribut warna diketahui bahwa yogurt yang paling disukai adalah yogurt dengan penambahan jenis penstabil pektin pada konsentrasi $0,01 \%$.

Uji statistik pada atribut aroma menunjukkan jika perlakuan jenis dan konsentrasi penstabil tidak berpengaruh nyata terhadap aroma yogurt jeruk. Asam laktat, asam asetat, senyawa asetildehid dan bahan-bahan lain yang dihasilkan selama proses fermentasi menyebabkan aroma khas pada yogurt (Triyono, 2010). Aroma yang dihasilkan oleh senyawa-senyawa hasil fermentasi tersebut cenderung sama, yaitu aroma khas yogurt, sehingga pada atribut aroma tidak berpengaruh nyata.

Atribut penampakan dinilai oleh panelis berdasarkan indera pengelihatan. Penampakan pada yogurt menjadi atribut yang penting untuk menentukan kualitasnya (Triyono, 2010). Hasil statistik menunjukkan jika perlakuan jenis dan konsentrasi penstabil menunjukkan hasil yang berbeda nyata ( $p$ value $\leq 0,05)$. Atribut penampakan ini dapat dikaitkan dengan nilai pengujian wheying off, pada minuman yogurt jeruk yang memiliki tingkat wheying tinggi, cenderung terlihat pemisahan whey, sehingga mempengaruhi penilaian penampakan dari panelis. Menurut penelitian Sutrisno et al., (2019), penggunaan penstabil CMC pada konsentrasi 1\%, dapat menghasilkan yogurt dengan penampakan yang disukai oleh panelis. Menurut penilaian panelis, minuman yogurt jeruk dengan penampakan yang paling disukai adalah perlakuan CMC pada konsentrasi $0,01 \%$.

Kualitas yogurt salah satunya juga ditentukan oleh parameter tekstur. Panelis memberikan penilaian terhadap tekstur saat yogurt tersebut dikonsumsi, indera yang digunakan dalam penilaian adalah lidah. Berdasarkan uji statistik menunjukkan jika perlakuan perbedaan jenis dan konsentrasi penstabil memberikan pengaruh terhadap atribut tekstur pada minuman yogurt jeruk. Hal ini diduga karena masing-masing perlakuan yogurt memiliki viskositas yang berbeda beda. Viskositas berkaitan dengan kekentalan produk. Semakin tinggi 
viskositas maka kekentalan produk semakin tinggi. Penambahan penstabil dapat menstabilkan tekstur yogurt (Sutrisno et al., 2019). Menurut penilaian panelis, minuman yogurt jeruk dengan tekstur yang paling disukai adalah perlakuan CMC pada konsentrasi 0,01\%.

Rasa merupakan atribut penilaian yang berpengaruh terhadap kualitas produk. Minuman yogurt jeruk memiliki rasa yang asam dengan intensitas yang berbeda. Rasa asam pada yogurt ini dapat dikaitkan dengan nilai $\mathrm{pH}$ yang dapat dilihat pada Tabel 1 . Semakin rendah nilai $\mathrm{pH}$ maka minuman yogurt jeruk cenderung memiliki rasa yang asam. Berdasarkan uji statistik, penambahan penstabil berpengaruh terhadap penilaian atribut rasa ( $p$ value $\leq 0,05)$, akan tetapi konsentrasi penstabil tidak berpengaruh. Menurut penilaian panelis, rasa yogurt jeruk yang paling disukai adalah pada penambahan CMC sebesar 0,05\%. Rasa asam pada yogurt berasal dari proses fermentasi laktosa oleh bakteri asam laktat (Triyono, 2010).

\section{KESIMPULAN}

Pemberian perlakuan perbedaan jenis penstabil berpengaruh terhadap karakteristik fisikokimia minuman yogurt jeruk diantaranya nilai $\mathrm{pH}$, TPT, vitamin $\mathrm{C}$, TAT, wheying off dan viskositas. Sedangkan perlakuan perbedaan konsentrasi penstabil berpengaruh terhadap wheying off dan viskositas minuman yogurt jeruk namun tidak berpengaruh terhadap nilai $\mathrm{pH}$, TPT, vitamin $\mathrm{C}$, dan TAT. Hasil interaksi antara jenis dan konsentrasi penstabil berpengaruh terhadap nilai $\mathrm{pH}$, vitamin $\mathrm{C}$, TAT, wheying off dan viskositas minuman yogurt jeruk namun tidak berpengaruh terhadap TPT. Penambahan penstabil dengan berbagai konsentrasi berpengaruh nyata terhadap nilai kesukaan pada warna, penampakan dan tekstur minuman yogurt jeruk.

\section{UCAPAN TERIMA KASIH}

Ucapan terima kasih diberikan kepada Endang Sutrisna, Sri Wahyuni, dan Yasita Eka Septiana selaku teknisi di Balai Penelitian Tanaman Jeruk dan Buah Subtropika yang telah membantu pelaksanaan penelitian ini.

\section{DAFTAR PUSTAKA}

Al-Bedrani, D. I., ALkaisy, Q. H., \& Mohammed, Z. M. (2019). Physicochemical, rheological and sensory properties of yogurt flavored with sweet orange (citrus sinensis) marmalade. IOP Conference Series: Earth and Environmental Science, 388(1). https://doi.org/10.1088/1755-1315/388/1/012052.

Andiç, S., Boran, G., \& Tuncturk, Y. (2013). Effects of carboxyl methyl cellulose and edible cow gelatin on physico-chemical, textural and sensory properties of yoghurt. International Journal of Agriculture and Biology, 15(2).

AOAC. (1995). Official Methods of Analysis of The Association of Analytical Chemist.

AOAC. (2005). Official Methods of Analysis of the Association of Official Agricultural Chemists 18th Edition (Vol. 46, Nomor 7, hal. 916-916). https://doi.org/10.2105/ajph.46.7.916-a.

Aprilia, D., Hermalia, S., Rahayu, R., \& Destiana, I. D. (2019). Pengaruh Perbedaan Konsentrasi Pisang sebagai Prebiotik Alami dan Pektin terhadap Karakteristik Cocogurt. 10th Industrial Research Workshop and National Seminar Proceeding, 41-46.

Arkan, N. D., Setyawardani, T., \& Astuti, T. Y. (2021). Pengaruh Penggunaan Pektin dengan Persentase yang Berbeda terhadap Nilai $\mathrm{pH}$ dan Total Asam Tertitrasi Yogurt Susu Sapi. Jurnal Teknologi Hasil Peternakan, 2(1), 1-7. https://doi.org/10.24198/jthp.v2i1.28302.

Atviolani, R. (2016). Pengaruh konsentrasi sukrosa dan pektin terhadap karakteristik marmalade buah naga merah (Hylocereus polyrhizus) [Skripsi]. Bandung : Universitas Pasundan.

Badan Standardisasi Nasional. (2009). SNI Yogurt No 2981:2009 (hal. 1-8). Badan Standardisasi Nasional.

Balitjestro. (2020). Jenis Jeruk Yang Berkembang di Indonesia - Balitjestro. http://balitjestro.litbang.pertanian.go.id/jenis-jeruk-yang-berkembang-di-indonesia/

Bekti, E., Prasetyowati, Y., \& Haryati, S. (2019). Berbagai Konsentrasi CMC (Carboxy Methyl Cellulose) terhadap Sifat Fisikokimia dan Organoleptik Selai Labu Siam (Sechium Edule). Jurnal Teknologi Pangan dan Hasil Pertanian, 14(2). https://doi.org/10.11164/jjsps.5.2_359_3.

Djurdjevic-Denin, J., Macej, O., \& Jovanovic, S. (2002). Viscosity of set-style yogurt as influenced by heat treatment of milk and added demineralized whey powder. Journal of Agricultural Sciences, Belgrade, 47(1), 45-56. https://doi.org/10.2298/jas0201045d.

Faisal, M., Saifullah, \& Mukhriza, T. (2019). Organoleptic analysis of yogurt with banana addition and stevia sweeteners. Rasayan Journal of Chemistry, 12(3), 1151-1156. 
https://doi.org/10.31788/RJC.2019.1235365.

Farikha, I. N., Anam, C., \& Widowati, E. (2013). Pengaruh jenis dan konsentrasi bahan penstabil alami terhadap karakteristik fisikokimia sari buah naga merah (Hylocereus polyrhizus) selama penyimpanan. Jurnal Teknosains Pangan, 2(1).

Farinde, E. O., Obatolu, V. A., Oyarekua, M. A., Adeniran, H. A., Ejoh, S. I., \& Olanipekun, O. T. (2010). Physical and microbial properties of fruit flavoured fermented cowmilk and soy milk (yoghurt-like) under different temperature of storage. African Journal of Food Science and Technology, 1(5), 120-127.

Fazilah, N. F., Hamidon, N. H., Ariff, A. B., Khayat, M. E., Wasoh, H., \& Halim, M. (2019). Microencapsulation of Lactococcus lactis Gh1 with Gum Arabic and Synsepalum dulcificum via Spray Drying for Potential Inclusion in Functional Yogurt. Molecules, 24(7). https://doi.org/10.3390/molecules24071422.

Gad, A. S., \& Mohamad, S. H. S. (2014). Effect of hydrocolloid type on physiochemical properties of nonfat drinkable yogurt fermented with ropy and non-ropy yogurt cultures. Comunicata Scientiae, 5(3), 318325.

Gaol, A. L., \& Hidayat, K. S. (2016). Pengaruh Kualitas Produk Terhadap Tingkat Kepuasan Konsumen Dan Loyalitas Konsumen. Jurnal Administrasi Bisnis (JAB)|Vol. 38 No. 1 September 2016, 38(1), 125-132.

Jannah, A. M., Legowo, A. M., Pramono, Y. B., \& Al-baarri, A. N. (2014). Total Bakteri Asam Laktat , pH , Keasaman, Citarasa dan Kesukaan Yogurt Drink dengan Penambahan Ekstrak Buah Belimbing. 3(2).

Jasim, M. A., Salih, G. M., \& Hamk, M. L. (2018). The Effect of Arabic Gum on Physicochemical and Sensory Properties of Camel Milk, Yogurt. Journal of Zankoy Sulaimani - Part A, 2(Special Issue), 97-104. https://doi.org/10.17656/jzs.10656.

Macit, E., \& Bakirci, I. (2017). Effect of different stablizers on quality characteristics of the set-type yogurt. African Journal of Biotechnology, 16(46), 2142-2151. https://doi.org/10.5897/ajb2017.16197.

Ningsih, E. L., Kayaputri, I. L., \& Setiasih, I. S. (2019). Pengaruh Penambahan CMC (Carboxy Methyl Cellulose) Terhadap Karakteristik Fisik Yoghurt Probiotik Potongan Buah Naga Merah. Jurnal Ilmu dan Teknologi Hasil Ternak, 19(1), 60-69. https://doi.org/10.21776/ub.jitek.2019.014.01.7.

Oni, Wa, Bahari, dan R. (2019). Kajian Sistem Agribisnis Jeruk Manis (Citrus sinensis) dalam Rangka Peningkatan Pendapatan Petani di Desa Konda Satu Kecamatan Konda Kabupaten Konawe Selatan. Jurnal Ilmiah Agribisnis, 4(5), 116-120.

Prayitno, S. S., Sumarmono, J., Rahardjo, A. H. D., \& Setyawardani, T. (2020). Modifikasi Sifat Fisik Yogurt Susu Kambing dengan Penambahan Microbial Transglutaminase dan Sumber Protein Eksternal. Jurnal Aplikasi Teknologi Pangan, 9(2), 77-82. https://doi.org/10.17728/jatp.6396.

Salih, Z. A., Siddeeg, A., Farga, A. A.-, Mousa, R. M. A., Husam, S. A., \& Zubair, A. S. Al. (2020). Physicochemical, Microbial and Sensory Characteristics of Yoghurt Processed by Adding Various Formulations of Gum Arabic and Guar Gum. Annual Research \& Review in Biology, November, 33-44. https://doi.org/10.9734/arrb/2020/v35i1130297.

Sebayang, F. (2019). The Utilization of Carboxymethyl Cellulose (Cmc) from Groundnut (Arachis Hypogaea L) Cellulose as Stabilizer for Cow Milk Yogurt. Journal of Chemical Natural Resources, 1(2), 38-51. https://doi.org/10.32734/jcnar.v1i2.1252.

Singh, G., Kapoor, I. P. S., \& Singh, P. (2011). Effect of volatile oil and oleoresin of anise on the shelf life of yogurt. Journal of Food Processing and Preservation, 35(6), 778-783. https://doi.org/10.1111/j.17454549.2011.00528.x

Sudarmadji, S., Haryono, B., \& Suhardi. (1997). Prosedur Analisa Untuk Bahan Makanan dan Pertanian. Liberty.

Sutrisno, O. D., Agustina, L., \& Al Hakim, H. M. (2019). Pengaruh Jenis Dan Konsentrasi Penstabil Pada Pembuatan Minuman Probiotik Kacang Nagara (Vigna unguiculata ssp. Cylindrica). Pro Food, 5(2), 496. https://doi.org/10.29303/profood.v5i2.113

Tamime, A. Y., \& Robinson, R. K. (2000). Yoghurt Science and Technology (Second Edi). Woodhead Publishing Limited.

Triyono, A. (2010). Mempelajari Pengaruh Maltodekstrin dan Susu Skim Terhadap Karakteristik Yoghurt 
Kacang Hijau (Phaseoulus radiatus L.). Seminar, 1-8.

Wahyudi, M. (2006). Proses pembuatan dan analisis mutu yoghurt. Buletin Teknik Pertanian, 11(12), 12-16.

Widianti, D. (2018). Penambahan Konsentrasi Sukrosa Dan Jenis Bahan Penstabil Terhadap Karakteristik Minuman Probiotik Yoghurt Santan [Universitas Pasundan]. http://repository.unpas.ac.id/40335/

Yousefi, M., \& Jafari, S. M. (2019). Recent advances in application of different hydrocolloids in dairy products to improve their techno-functional properties. Trends in Food Science and Technology, 88(October 2018), 468-483. https://doi.org/10.1016/j.tifs.2019.04.015. 